\title{
Time, Firm and Country Effects on Performance: An Analysis under the Perspective of Hierarchical Modeling with Repeated Measures
}

\author{
Luiz Paulo Lopes Fávero ${ }^{\dagger}$ \\ University of São Paulo
}

\begin{abstract}
The literature is unclear about how firm and country effects influence performance over time. Under the initial hypotheses that there are significant changes in the performance of companies operating in Brazil in recent years and that these variations are due to existing characteristics in each firm and to the country of origin, this study considers, through the use of hierarchical modeling with repeated measures, an approach that allows analyzing random effects as an alternative to evaluate the evolution of profitability. The findings, based on a sample of 523 firms from 18 countries over 8 years (1998-2005), for a total of 2,545 observations, is that only the firm effect is representative to differentiate the average performance and growth rates of this performance among companies in the period studied. The results contribute to the understanding of the multilevel factors that determine firm performance over time.
\end{abstract}

Keywords: Performance analysis; hierarchical models; repeated measures; firm effect; country effect.

Received in 05/16/2008; revised in 10/19/2008; accept in 04/12/2008.

Corresponding authors:

${ }^{\dagger}$ Professor of Faculty of Economics, Administration e Accounting - University of São Paulo.

Address: Av. Prof. Luciano Gualberto, 908 - FEA 3 - sala 237.

University City - São Paulo - SP - Brazil - CEP:05508-900

e-mail:lpfavero@usp.br

Telephone: (11) 3091-5820

Editor's note: This paper was accepted by Alexsandro Broedel Lopes. 


\section{INTRODUCTION}

$\mathrm{M}$

any studies in the field of positive accounting in Brazil and the world address aspects of the effects generated by a determined group of variables on a specific behavior that provides information to decision makers. The current Brazilian literature reflects the transformations that have occurred in the international panorama, in which investors have been demanding greater disclosure, accountability and ethical behavior of firms (LIMA, LIMA, FÁVERO and GALDI, 2007). In this respect, there is a growing number of accounting works using multivariate tools applied to quantitative data, seeking to create models that explain reality and to verify empirically the phenomena observed.

According to Iudícibus and Lopes (2004, pp. 15-16), the positive accounting approach aims to describe how accounting practices develop in the real world and predict what will occur. In this fashion, the objective is to investigate the reasons organizations reach certain decisions in detriment to others, within a market and economic context.

Therefore, as posited by Watts and Zimmerman (1986) and Iudícibus and Lopes (2004), the objectives of accounting theory are to explain and predict the practice of accounting, without the need, strictly speaking, for the treatment to address only future phenomena, instead in many cases aimed at existing but not yet observed behaviors.

Within this approach, many works have used quantitative data analysis techniques to solve problems and formulate models that explain and predict reality, as cited by Holthausen and Watts (2001, pp. 3-75). According to Barth, Beaver and Landsman (2001, pp. 77-104), econometric techniques are used in many relevant works where otherwise the inferences could have limited validity. However, it is fundamental that the appropriate choice of each statistical technique be based on an underlying theory and be in accordance with the question investigated.

In this sense, I adopt the multilevel approach to examine the effect of the country of origin and firm characteristics on the performance of the companies listed in the ranking of the 500 Best and Biggest Companies of the magazine Exame ${ }^{1}$, from 1998 to 2005 . According to Goldszmidt, Brito and Vasconcelos (2007), the search for the origins of firms' performance is a central theme in research on strategy, and the study of the variance components of this performance has offered important empirical support to this search.

Also according to Goldszmidt, Brito and Vasconcelos (2007), this line of research calls on the works of Schmalensee (1985, pp. 341-351) and Rumelt (1991, pp. 167-185), which were followed by a series of other studies that analyzed the firm, industry and year effects, such as those of Roquebert, Phillips and Westfall (1996, pp. 653-664), McGahan and Porter (1997, pp. 15-30), Brush and Bromiley (1997, pp. 825-835), Brush, Bromiley and Hendrickx (1999, pp. 519-547) and Bowman and Helfat (2000, pp. 1-23).

This article contributes to the study of the sources of heterogeneity of firms' performance over time, specifically regarding the firm and country effects, by means of multilevel techniques. First it evaluates the performance variations among firms of the same country and those from different countries over time, and then investigates the variables related to the firms and the countries that possibly explain the variations among firms over time. Therefore, an approach at three levels is used. The first is related to the time variation (repeated measure), the second to the characteristics of the firms, and the third to the variables of the countries.

${ }^{1}$ I thank Professor Ariovaldo dos Santos for providing the data. 
Through the hierarchical modeling technique with repeated measures, this work examines the firm and country of origin effects of a sample of 523 firms from 18 countries, over a period of 8 hears (1998-2005).

The next two sections present a review of the hierarchical models and discuss the main concepts related to the three-level hierarchical modeling with repeated measures, with emphasis on the works that investigate the effects of the firm and place of origin on performance. The third section presents the method and model proposed. The fourth section presents and discusses the results, and the fifth concludes.

\section{Multilevel Models and the Firm and Country Effects on Performance ${ }^{2}$}

Most of the data studied in the social sciences come from phenomena in which the subjects naturally appear in hierarchical form (SOTO and MORERA, 2005). According to Raudenbush, Bryk, Cheong, Congdon and du Toit (2004), behavioral, social and performancevariable data commonly have a nested structure and each sub-model represents the structural relations and residual variability occurring at that level.

There are many situations with a hierarchical structure, such as students attending schools and these belonging to school districts, patients in hospitals, voters in precincts, residences in cities and these in states, individuals in sectors of the economy and firms in sectors or countries of origin. The hierarchies correspond to the idea according to which the subjects within the same group share a set of stimuli that favor homogeneity.

According to Gelman (2006, pp. 432-435), multilevel models are a generalization of regression methods, and thus can be used for a variety of purposes, including prediction, data reduction causal inference based on trials and observational studies. Recent contributions on the theme are found in Hofmann (1997, pp. 723-744), Kreft and de Leeuw (1998), Snijders and Bosker (1999), Raudenbush and Bryk (2002), Hox (2002) and Goldstein (2003).

In comparison with the classic linear regression or covariance analysis models, multilevel models have the advantage of analyzing hierarchically structured data. These models propose an analytical structure in which the distinct levels at which the data are connected can be recognized, with each sub-level represented by its own model (DRAPER, 1995, pp. 115-147). Each of these sub-models, according to Soto and Morera (2005), expresses the relationship of the variables at a determined level and specifies how the variables at this level influence the relations that are established at other levels.

A classic regression model, applied for example to the analysis of the performance of firms from a certain country, might be:

$$
\mathrm{y}_{\mathrm{i}}=\beta_{0}+\beta_{1} \cdot \mathrm{X}_{1 \mathrm{i}}+\mathrm{r}_{\mathrm{i}}
$$

Equation (1) represents the relationship between the performance variable (e.g., the firm's profitability) and the predictive variable (e.g., if it is in the retail or industrial sector). The constant $\beta_{0}$ represents the average profitability of retail firms from that country. The coefficient $\beta_{1}$ is the slope of the straight regression line and represents the increase in profitability when considering firms in the industrial segment. The term $r_{i}$ refers to how much

\footnotetext{
${ }^{2}$ The terms time effect, firm effect and country effect refer, respectively, to the effects that the passage of time, the attributes of organizations and the characteristics of the country of origin exercise on a determined performance variable (in this case, the adjusted profitability of each firm, as disclosed in the ranking of the 500 Best and Biggest Companies of Exame magazine).
}

BBR, Braz. Bus. Rev. (Eng. ed., Online),

Vitória, v. 5, n. 3, Art. 1, p. 163 - 180, sep. - dec. 2008

www.bbronline.com.br 
the profitability of firm i differs from the expected return of firms that have the same characteristic (retailers or industries). A generic graph can be plotted to illustrate the case:

Figure 1: Classic regression model for companies from one country

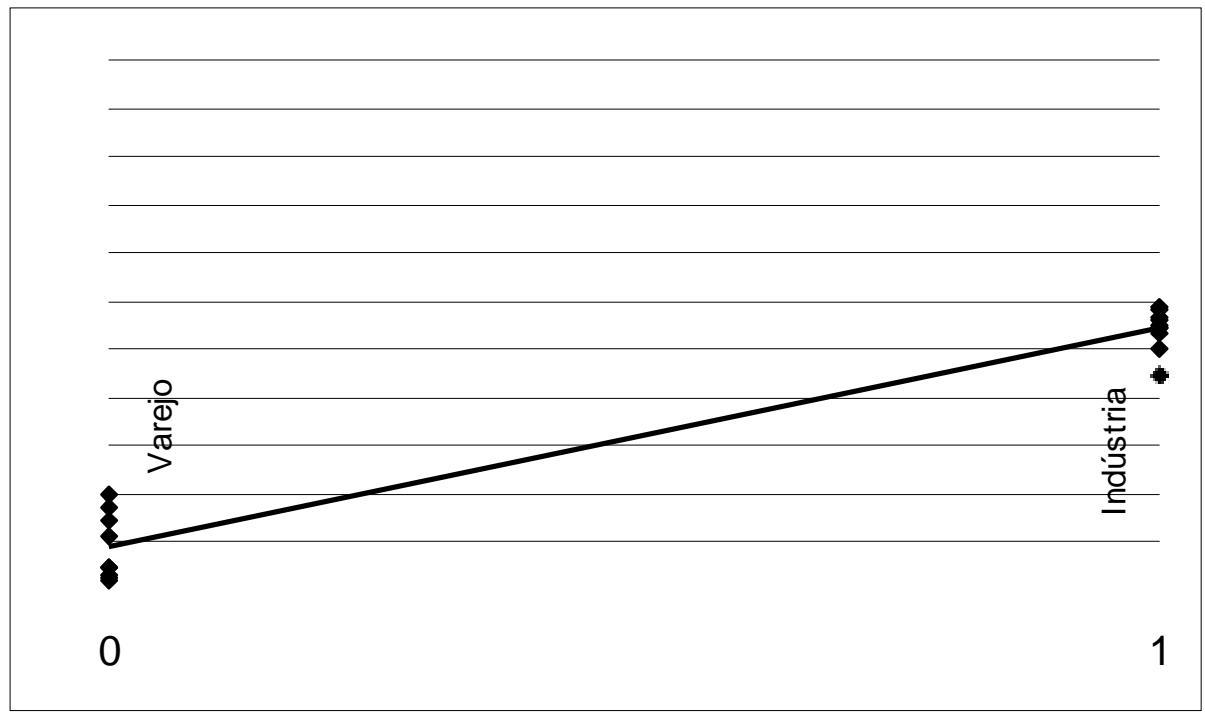

Source Adapted from Soto and Morera, 2005.

On the other hand, if the analysis is carried out for firms from two different countries, two different equations need to be defined:

$$
\begin{aligned}
& y_{i 1}=\beta_{01}+\beta_{11} \cdot X_{11 i}+r_{i 1} \\
& y_{i 2}=\beta_{02}+\beta_{12} \cdot X_{12 \mathrm{i}}+r_{i 2}
\end{aligned}
$$

In these equations, the coefficients $\beta_{01}$ and $\beta_{02}$ represent the average expected returns of the firms from each of the countries. The coefficients $\square_{11}$ and $\square_{12}$ are the slopes, and analogously represent the increments in the average returns when the firms' segments are altered. Just as above, a new generic graph can be drawn: 
Figure 2: Classic regression model for companies from two countries

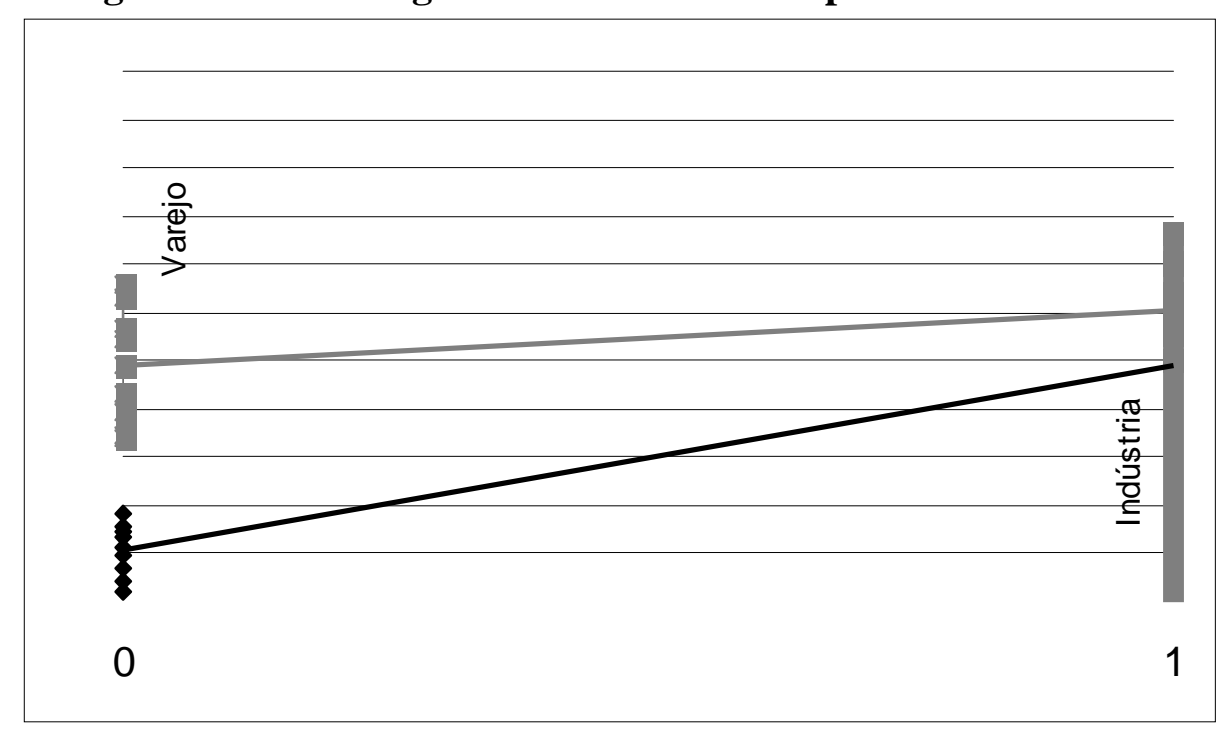

Source Adapted from Soto and Morera, 2005.

In reality there are many countries of origin that can mutually vary, both with respect to the intercepts and the slopes, so it is not very practical to estimate a regression equation for each of them.

Hence, the estimation of the firm and country effects requires a two-level model, with $\mathrm{j}$ countries at level 2 and $i$ firms at level 1 . Formally, there are $\mathrm{i}=1, \ldots, \mathrm{n}_{\mathrm{j}}$ units at level 1 (in this case, firms), which are nested with each $\mathrm{j}=1, \ldots, \mathrm{J}$ units at level 2 (in this case, countries). Therefore, the level 1 model can be written as:

$$
\begin{aligned}
& y_{i j}=\beta_{0 j}+\beta_{1 j} \cdot X_{1 i j}+\beta_{2 j} \cdot X_{2 i j}+\ldots+\beta_{Q j} \cdot X_{Q i j}+r_{i j} \\
& y_{i j}=\beta_{0 j}+\sum_{q=1}^{Q} \beta_{q j} \cdot X_{q i j}+r_{i j}
\end{aligned}
$$

where:

- $\beta_{\mathrm{qj}}(\mathrm{q}=0,1, \ldots, \mathrm{Q})$ are the level 1 coefficients;

- $\mathrm{X}_{\mathrm{qij}}$ is the predictive variable vector q of level 1 (firm variables) for case $\mathrm{i}$ (firm) of unit $\mathrm{j}$ (country);

- $r_{\mathrm{ij}}$ is the random effect variable of level 1; and

- $\sigma^{2}$ is the variance of $r_{i j}$ (level 1 variance). It is assumed that the random term $r_{i j}$ $\mathrm{N}\left(0, \sigma^{2}\right)$.

Likewise, the level 2 model can be written as:

$$
\begin{aligned}
& \beta_{\mathrm{qj}}=\gamma_{\mathrm{q} 0}+\gamma_{\mathrm{q} 1} \cdot \mathrm{W}_{1 \mathrm{j}}+\gamma_{\mathrm{q} 2} \cdot \mathrm{W}_{2 \mathrm{j}}+\ldots+\gamma_{\mathrm{qS}} \cdot \mathrm{W}_{\mathrm{q}} \mathrm{iq}_{\mathrm{q}}+\mathrm{u}_{\mathrm{qj}} \\
& \beta_{\mathrm{qj}}=\gamma_{\mathrm{q} 0}+\sum_{\mathrm{s}=1}^{\mathrm{S}_{\mathrm{q}}} \gamma_{\mathrm{qs}} \cdot \mathrm{W}_{\mathrm{sj}}+\mathrm{u}_{\mathrm{qj}}
\end{aligned}
$$


where:

$-\gamma_{\mathrm{qs}}\left(\mathrm{q}=0,1, \ldots, \mathrm{S}_{\mathrm{q}}\right)$ are the level 2 coefficients;

- $\mathrm{W}_{\mathrm{sj}}$ is the predictive variable vector of level 2 (country variables); and

- $\mathrm{u}_{\mathrm{qj}}$ is the random effect of level 2. It is assumed that for each unit $\mathrm{j}$, the vector $\left(\mathrm{u}_{0 \mathrm{j}}\right.$, $\left.\mathrm{u}_{1 \mathrm{j}}, \ldots, \mathrm{u}_{\mathrm{Qj}}\right)^{\prime}$ has a multivariate normal distribution, with each element of $\mathrm{u}_{\mathrm{qj}}$ having mean zero and variance $\operatorname{Var}\left(\mathrm{u}_{\mathrm{qj}}\right)=\tau_{\mathrm{qq}}$.

For each of the random effects $q$ and $q^{\prime}$, it is given that:

$$
\operatorname{Cov}\left(\mathrm{u}_{\mathrm{qj}}, \mathrm{u}_{\mathrm{q}^{\prime} \mathrm{j}}\right)=\tau_{\mathrm{qq}}
$$

Similar models have been widely used in the literature on strategy to compare variances of variables present at the firm and segment levels for composition of the performance of firms. In this line, of special note are the works of Mauri and Michaels (1998, pp. 211-219), Chang and Singh (2000, pp. 739-752), Ruefli and Wiggins (2003, pp. 861-879) and Short, Ketchen Jr., Palmer and Hult (2007, pp. 147-167).

Other authors have analyzed the country effect on firms' performance, among them Collins (1990, pp. 271, 288), Christmann, Day and Yip (1999, pp. 241-265), Brito and Vasconcelos (2003), Hawawini, Subramanian and Verdin (2004, pp. 121-135), Makino, Isobe and Chan (2004, pp. 1027-1043), Makino, Beamish and Zhao (2004, pp. 377-392) and Goldszmidt, Brito and Vasconcelos (2007). Others have studied the municipal or microlocation effect to evaluate certain phenomena in people of firms, such as Price, Nero and Gelman (1996, pp. 922-936) and Gelman (2006, pp. 432-435).

This work examines the country effect on firms' performance under a time perspective, that is, by using hierarchical models with repeated measures.

\section{Three-Level Hierarchical Models with Repeated Measures}

Models that account for variations over time to evaluate performance are increasingly used and represent new challenges when formulating research projects and creating unbiased indicators (RAUDENBUSK and BRYK, 2002). Bliese and Ployhart (2002, pp. 362-387) show how the random coefficients model can be used to develop and test growth models when analyzing longitudinal data. According to Short, Ketchen Jr., Bennett and du Toit (2006, pp. 259-284), hierarchical models with repeated measures offer additional advantages by permitting researchers to model specific predictive variables at each level of analysis, offering answers about how exact the influences are over time at the level of the firm, segment or location.

Three-level models consist of three sub-models, in which there are $t=1, \ldots, \mathrm{T}_{\mathrm{ij}}$ years at level 1 , and these years are nested in each $\mathrm{i}=1, \ldots, \mathrm{n}_{\mathrm{j}}$ firms, which in turn are nested in $\mathrm{j}=1$, ..., J countries. Hence, level 1 is described by:

$$
\mathrm{y}_{\mathrm{tij}}=\pi_{0 \mathrm{ij}}+\pi_{1 \mathrm{ij}} \cdot \mathrm{ANO}_{\mathrm{tij}}+\mathrm{e}_{\mathrm{tij}}
$$

where:

$$
\text { - } t=1,2, \ldots, T_{i j}(\text { years }), j=1,2 \ldots, J \text { (countries) and } i=1,2, \ldots, n_{j}(\text { firms })
$$


- $\pi_{0 \mathrm{ij}}$ is the expected value of the performance variable (mean) of firm ij in year 1 ;

- $\pi_{1 \mathrm{ij}}$ is the growth rate of the performance variable of firm $\mathrm{ij}$; and

- $\sigma^{2}$ is the variance of $\varepsilon_{i j}$ (variance of a determined firm over time). It is assumed that the random term $\mathrm{e}_{\mathrm{tij}} \sim \mathrm{N}\left(0, \sigma^{2}\right)$.

Each coefficient at level 1 becomes a dependent variable in the level 2 model, which can thus be written as:

$$
\begin{aligned}
& \pi_{\mathrm{pij}}=\beta_{\mathrm{p} 0 \mathrm{j}}+\beta_{\mathrm{p} 1 \mathrm{j}} \cdot \mathrm{X}_{1 \mathrm{ij}}+\beta_{\mathrm{p} 2 \mathrm{j}} \cdot \mathrm{X}_{2 \mathrm{ij}}+\ldots+\beta_{\mathrm{pQ} \mathrm{p}} \cdot \mathrm{X}_{\mathrm{Q}_{\mathrm{p} j} \mathrm{j}}+\mathrm{r}_{\mathrm{pij}} \\
& \pi_{\mathrm{pij}}=\beta_{\mathrm{p} 0 \mathrm{j}}+\sum_{\mathrm{q}=1}^{\mathrm{Q}_{\mathrm{p}}} \beta_{\mathrm{pqj}} \cdot \mathrm{X}_{\mathrm{qij}}+\mathrm{r}_{\mathrm{pij}}
\end{aligned}
$$

where:

- $\beta_{\text {pqj }}\left(\mathrm{q}=0,1, \ldots, \mathrm{Q}_{\mathrm{p}}\right)$ are the level 2 coefficients;

- $\mathrm{X}_{\mathrm{qij}}$ is the predictive variable vector of level 2; and

- $r_{p i j}$ is the random effect at level 2. It is assumed that for each unit $i$, the vector $\left(r_{0 i j}\right.$, $\left.r_{1 i j}, \ldots, r_{p i j}\right)^{\prime}$ has a multivariate normal distribution, in which each element $r_{p i j}$ has mean zero and variance $\operatorname{Var}\left(\mathrm{r}_{\mathrm{pij}}\right)=\tau_{\pi \mathrm{pp}}$.

For each pair of random effects $\mathrm{p}$ and $\mathrm{p}^{\prime}$, it is given that:

$$
\operatorname{Cov}\left(r_{p i j}, r_{p^{\prime} i j}\right)=\tau_{\pi p p^{\prime}}
$$

Analogously, the level 3 model can be written as:

$$
\begin{aligned}
& \beta_{\mathrm{pqj}}=\gamma_{\mathrm{pq} 0}+\gamma_{\mathrm{pq} 1} \cdot \mathrm{W}_{1 \mathrm{j}}+\gamma_{\mathrm{pq} 2} \cdot \mathrm{W}_{2 \mathrm{j}}+\ldots+\gamma_{\mathrm{pq} \mathrm{S}_{\mathrm{pq}}} \cdot \mathrm{W}_{\mathrm{s} \mathrm{pq}}+\mathrm{u}_{\mathrm{pqj}} \\
& \beta_{\mathrm{pqj}}=\gamma_{\mathrm{pq} 0}+\sum_{\mathrm{s}=1}^{\mathrm{s}_{\mathrm{p}}} \gamma_{\mathrm{pqs}} \cdot \mathrm{W}_{\mathrm{sj}}+\mathrm{u}_{\mathrm{pqj}}
\end{aligned}
$$

where:

- $\gamma_{\mathrm{pqs}}\left(\mathrm{s}=0,1, \ldots, \mathrm{S}_{\mathrm{pq}}\right)$ are the level 3 coefficients;

- $W_{\mathrm{sj}}$ is the predictive variable vector of level 3; and

- $\mathrm{u}_{\text {pqj }}$ is the random effect at level 3. It is assumed that for each unit of level 3, the random effects vector (the $u_{p q j}$ terms) has a multivariate normal distribution, with mean zero and covariance matrix $T_{\beta}$, whose maximum dimension depends on the number of coefficients specified, with the presence of random effects .

$$
\sum_{\mathrm{p}=0}^{\mathrm{p}}\left(\mathrm{Q}_{\mathrm{p}}+1\right) \mathrm{x} \sum_{\mathrm{p}=0}^{\mathrm{p}}\left(\mathrm{Q}_{\mathrm{p}}+1\right)
$$


Even 20 years after the seminal work of Schmalensee, the themes still attracts much interest. Many recent works have applied hierarchical models with repeated measures to evaluate firms' performance, such as Bergh (1993, pp. 683-705), Bergh (1995, pp. 16921708), Deadrick, Bennett and Russell (1997, pp. 745-757), Adner and Helfat (2003, pp. 10111025), Hough (2006, pp. 45-61), Misangyi, Lepine, Algina and Goeddeke (2006, pp. 5-28), Short, Ketchen Jr. Bennett and du Toit (2006, pp. 256-284) and Goldszmidt, Brito and Vasconcelos (2007).

\section{Definition of the Variables, Hypotheses and Method}

The use of models that consider the variation over time in evaluating performance is increasingly frequent and represents new challenges for the formulation of problems that seek to measure firms' performance (RAUDENBUSH and BRYK, 2002). According to Short, Ketchen Jr., Bennett and du Toit (2006, pp. 259-284), the application of hierarchical models permits testing the relationship of firms' performance with various environmental variables simultaneously. Hence, the use of this type of modeling enables developing new avenues of research to determine the influences of temporal, organizational and even regional aspects on companies' performance, leading to new strategic formulations. The sample, variables and hypotheses tested here and the model itself are presented next.

\subsection{Sample and Choice of Variables}

The data for this study were obtained from the database of the 500 Best and Biggest Companies of Exame magazine. Initially the data were taken from all the sets of firms in the period from 1998 to 2005 . The original base had nearly 1000 firms, from 22 countries over the eight-year period, for a total of 7,384 observations.

Following the same logic proposed by Goldszmidt, Brito and Vasconcelos (2007) regarding criteria to exclude observations, I eliminated firms with incomplete data regarding the explanatory variables or performance variable. Besides this, I sought to avoid indeterminacy in allocating the different effects due to the presence of fewer than two cases in each factor. I thus only kept firms where the dependent variable was available in the database for two or more periods, as well as instances where there were two or more firms from the same country in a determine year.

The final sample was composed of 523 firms from 18 countries, making 2,545 observations. This treatment allows the advantage of using multilevel models, which permit verifying what firm or country effects best explain the variance in performance over time.

The performance variable was the adjusted return as given in the mentioned ranking. The variables for study at levels 2 and 3 also were obtained from this same database and are shown in Chart 1 below:

Chart 1: Definition of the variables at levels 2 and 3

Level 2 Variables (Firm)

Segment (Services, Industry or Commerce ${ }^{3}$ )

Dummy Variables:

Services: $\mathrm{IND}=0$ and $\mathrm{COM}=0$

Industry: $\mathrm{IND}=1$ and $\mathrm{COM}=0$

Commerce: $\mathrm{IND}=0$ and $\mathrm{COM}=1$

${ }^{3}$ Commercial firms include both wholesalers and retailers.

BBR, Braz. Bus. Rev. (Eng. ed., Online),

Vitória, v. 5, n. 3, Art. 1, p. 163 - 180, sep. - dec. 2008

www.bbronline.com.br 


\begin{tabular}{|l|l|}
\hline Private or Government-Controlled & $\begin{array}{l}\text { Dummy Variable: } \\
\text { Private: GOVT }=0 \\
\text { Government: GOVT }=1\end{array}$ \\
\hline Level 3 Variables (Country) & NCI \\
\hline National Competitiveness Index & PCGDP \\
\hline Per Capita GDP & $\begin{array}{l}\text { Dummy: } \\
\text { Not Part of the G8: G8 =0 } \\
\text { Part of the G8: G8 }=1\end{array}$ \\
\hline Part of the G8 &
\end{tabular}

According to Chart 1, the firm variables (level 2) refer to the segments of activity and whether or not the firm is state owned. Since both are qualitative, it is necessary to define a reference category for each of them. For segment, this was services. Thus, the two dummy variables (IND and COM) created to represent the three categories are both zero for service firms. Likewise, for industrial firms, the IND dummy is 1 and the COM dummy is zero, and for commercial firms, COM is 1 and IND is zero. The same reasoning applies to whether or not a company is controlled by the government, except since there are only two categories, only one dummy is necessary.

For the variables representing the firms' countries of origin (level 3), two are quantitative (NCI and PCGDP) and correspond to the national competitiveness index and per capital gross domestic product of each company's country of origin, respectively. Finally, the variable regarding whether or not a firm's country of origin is part of the G8 block is represented by a dummy, whose value is 1 for countries that belong to the G8 and zero otherwise.

\subsection{Hypotheses Tested}

This work analyzes whether there are significant differences in firms' performance over time, whether these differences are due to variations of the firms and countries of origin, and if so, what reasons can account for these differences.

The hypotheses tested follow the logic proposed by Short, Ketchen Jr., Bennett and du Toit (2006, pp. 259-284) and can be described as follows:

Hypothesis 1: There is significant variability in the performance of the firms over time.

Hypothesis 2: There is significant variability in the performance over time of firms in a single country.

Hypothesis 3: There is significant variability in the performance over time of firms from different countries.

Hypothesis 4: The performance of firms follows a linear trend over time and the variance between them is significant.

Hypothesis 5: There are characteristics of the firms, such as segment of activity or whether or not they are state owned, that explain the variation in performance over time.

Hypothesis 6: The characteristics of the countries of origin, such as the competitiveness index, per capita GDP or inclusion in the G8, explain the differences in performance over time of the firms. 
The method used to test these hypotheses and the models proposed are presented next.

\subsection{Method}

The method for dealing with hierarchical models with repeated measures involves a series of nested regressions that are defined interactively through maximum likelihood estimation in the complete concept (RAUDENBUSH and BRYK, 2002). According to Hofmann, Jacobs and Baratta (1993, pp. 194-204) and Short, Ketchen Jr., Bennett and du Toit (2006, pp. 259-284), hierarchical models are more suitable than any other technique to analyze repeated measures, since they are capable of investigating and identifying patterns of systematic change of the performance variable individually and over time between the observations being studied. Therefore, this method of analysis considers a single performance path for each firm, taking into consideration the presence of random effects between observations to explain the evolution of the respective performances over time.

The models use three levels of analysis that represent, respectively, the individual changes in performance of firms over time (level 1), the variation in performance of firms from a single country (level 2) and the variation among countries (level 3).

To check the first three hypotheses, I use a model without predictive variables (null model), which offers estimations of the variance components for each firm (over time), among firms and among countries. The model provides $\square^{2}$ tests for the components among firms and countries (RAUDENBUSH, BRYK, CHEONG, CONGDON and du TOIT, 2004). Hence, the null model can be written as:

\section{Null Model}

Level 1 (repeated measure):

$\mathrm{RET}_{\mathrm{tij}}=\pi_{0 \mathrm{ij}}+\mathrm{e}_{\mathrm{tij}}, \quad \mathrm{e}_{\mathrm{tij}} \sim \mathrm{NID}\left(0, \sigma^{2}\right)$

RET: performance variable represented by the adjusted return;

$\mathrm{t}=1,2, \ldots, \mathrm{T}_{\mathrm{ij}}$ (years), $\mathrm{j}=1,2 \ldots, \mathrm{J}$ (countries) e $\mathrm{i}=1,2, \ldots, \mathrm{n}_{\mathrm{j}}$ (firms);

$\pi_{0 \mathrm{ij}}$ : expected RET (mean) of firm $\mathrm{ij}$ in year 1 (1998); and

$\sigma^{2}$ : "within" variance of the firm.

Level 2 (Firm):

$\pi_{0 \mathrm{ij}}=\beta_{00 \mathrm{j}}+\mathrm{r}_{0 \mathrm{ij}}, \quad \mathrm{r}_{0 \mathrm{ij}} \sim \mathrm{NID}\left(0, \tau_{\pi_{-} 0}\right)$

$\beta_{00 j:}$ mean of the expected RETs in 1998 of country $\bar{j}$; and

$\tau_{\pi_{-}}$: variance of the expected RETs in 1998 of country $j$.

Level 3 (Country):

$\beta_{00 \mathrm{j}}=\gamma_{000}+\mathrm{u}_{00 \mathrm{j}}, \quad \mathrm{u}_{00 \mathrm{j}} \sim \mathrm{NID}\left(0, \tau_{\beta_{-}}\right)$

Yo00: general mean of the expected RETs in 1998; and

$\tau_{\beta} \_$: variance of the expected RETs in 1998.

To check the fourth hypothesis, I propose two models that include a trend component (variation over time) at level 1 . The first model does not include random effects and only tests whether firms' performance follows a linear time trend. The second of these models includes random effects and tests whether there is significant variance of the performance trend among firms over time.

\section{Linear Trend Model without Random Effects}

BBR, Braz. Bus. Rev. (Eng. ed., Online),

Vitória, v. 5, n. 3, Art. 1, p. 163 - 180, sep. - dec. 2008

www.bbronline.com.br 
Level 1 (Repeated Measure):

$\mathrm{RET}_{\mathrm{tij}}=\pi_{0 \mathrm{ij}}+\pi_{1 \mathrm{ij}} . \mathrm{ANO}_{\mathrm{tij}}+\mathrm{e}_{\mathrm{tij}}, \quad \mathrm{e}_{\mathrm{tij}} \sim \mathrm{NID}\left(0, \sigma^{2}\right)$

RET: performance variable represented by the adjusted return;

$\mathrm{t}=1,2, \ldots, \mathrm{T}_{\mathrm{ij}}$ (years), $\mathrm{j}=1,2 \ldots, \mathrm{J}$ (countries) e $\mathrm{i}=1,2, \ldots, \mathrm{n}_{\mathrm{j}}$ (firms);

$\pi_{0 \mathrm{ij}}$ : expected RET (mean) of firm ij in year 1 (1998);

$\pi_{1 \mathrm{ij}}$ : growth rate of the RET of firm ij; and

$\sigma^{2}$ : "within" variance of the firm.

Level 2 (Firm):

$\pi_{0 \mathrm{ij}}=\beta_{00 \mathrm{j}}+r_{0 \mathrm{ij}}, \quad \mathrm{r}_{0 \mathrm{ij}} \sim \operatorname{NID}\left(0, \tau_{\pi_{-}}\right)$

$\pi_{1 \mathrm{ij}}=\beta_{10 \mathrm{j}}$

$\beta_{00 j}$ : mean of the expected RETs in 1998 in country $j$;

$\beta_{10 j}$ : mean of the expected growth rates in country $j$; and

$\tau_{\pi_{\_}} 0$ : expected variance of the RETs in 1998 of country $j$.

Level 3 (Country):

$\beta_{00 j}=\gamma_{000}+\mathrm{u}_{00 \mathrm{j}}, \quad \mathrm{u}_{00 \mathrm{j}} \sim \operatorname{NID}\left(0, \tau_{\beta} \_0\right)$

$\beta_{10 \mathrm{j}}=\gamma_{100}$

$\gamma_{000}$ : general mean of the expected RETs in 1998;

$\gamma_{100}$ : mean growth rate of the expected RETs; and

$\tau_{\beta \_} \_$: variance among the expected RETs in 1998.

\section{Linear Trend Model with Random Effects}

Level 1 (Repeated Measure):

$\mathrm{RET}_{\mathrm{tij}}=\pi_{0 \mathrm{ij}}+\pi_{1 \mathrm{ij}} . \mathrm{ANO}_{\mathrm{tij}}+\mathrm{e}_{\mathrm{tij}}, \quad \mathrm{e}_{\mathrm{tij}} \sim \operatorname{NID}\left(0, \sigma^{2}\right)$

RET: performance variable represented by the adjusted return;

$\mathrm{t}=1,2, \ldots, \mathrm{T}_{\mathrm{ij}}$ (years), $\mathrm{j}=1,2 \ldots, \mathrm{J}$ (countries) e $\mathrm{i}=1,2, \ldots, \mathrm{n}_{\mathrm{j}}$ (firms);

$\pi_{0 i j:}$ expected RET (mean) of firm ij in year 1 (1998);

$\pi_{1 i \mathrm{ij}}$ : growth rate of the RET of firm ij; and

$\sigma^{2}$ : "within" variance of the firm.

Level 2 (Firm):

$\pi_{0 \mathrm{ij}}=\beta_{00 \mathrm{j}}+\mathrm{r}_{0 \mathrm{ij}}, \quad \mathrm{r}_{0 \mathrm{ij}} \sim \operatorname{NID}\left(0, \tau_{\pi_{-}}\right)$

$\pi_{1 \mathrm{ij}}=\beta_{10 \mathrm{j}}+\mathrm{r}_{1 \mathrm{ij}}, \quad \mathrm{r}_{1 \mathrm{ij}} \sim \operatorname{NID}\left(0, \tau_{\pi_{-} 1}\right)$

$\beta_{00 j}$ : mean of the expected RETs in 1998 of country $j$

$\beta_{10 j}$ : mean of the expected growth rates in countryj

$\tau_{\pi \_0}$ : variance of the expected RETs in 1998 of country $j$

$\tau_{\pi_{-} 1}$ : variance of the expected growth rates in country $\mathrm{j}$

Level 3 (Country):

$\beta_{00 j}=Y_{000}+u_{00 j}, \quad u_{00 j} \sim \operatorname{NID}\left(0, \tau_{\beta} \_0\right)$

$\beta_{10 j}=\gamma_{100}+u_{10 j}, \quad u_{10 j} \sim \operatorname{NID}\left(0, \tau_{\beta_{-} 1}\right)$

Yo00: general mean of the expected RETs in 1998

Y100: mean of the growth rate of the expected RETs;

$\tau_{\beta_{\beta} 0}$ : variance among the expected RETs in 1998

$\tau_{\beta \_1}$ : variance among the expected growth rates. 
According to Short, Ketchen Jr., Bennett and du Toit (2006, pp. 259-284), the significance of the individual changes in performance is tested in two ways. The first is a $\square^{2}$ test, which compares the deviation statistics between the model with year effect (linear trend model) and the null model. The second employs a t-test for the fixed effects and a $\square^{2}$ test for the variance components. The significance of the fixed effect for the periods suggests that the time effect is constant for all firms. However, the inclusion of the random effects helps to check for the existence of significant variability in performance over time, among firms of a single country (level 2) and among firms from different countries (level 3).

If the previous hypotheses are not rejected, predictive variables are included in levels 2 and 3 to check hypotheses 5 and 6 , so that the model becomes:

\section{Complete Model}

Level 1:

$\operatorname{RET}_{\mathrm{tij}}=\pi_{0 \mathrm{ij}}+\pi_{1 \mathrm{ij}} \cdot \mathrm{ANO}_{\mathrm{tij}}+\mathrm{e}_{\mathrm{tij}}$

Level 2:

$\left.\pi_{0 i \mathrm{ij}}=\beta_{00 \mathrm{j}}+\beta_{01 \mathrm{j} .} . \mathrm{IND}\right)+\beta_{02 \mathrm{j} .}(\mathrm{COM})+\beta_{03 \mathrm{j}} .(\mathrm{GOVT})+\mathrm{r}_{0 \mathrm{ij}}$
$\pi_{1 \mathrm{ij}}=\beta_{10 \mathrm{j}}+\beta_{11 \mathrm{j} .} .(\mathrm{IND})+\beta_{12 \mathrm{j} .}(\mathrm{COM})+\beta_{13 \mathrm{j} .} .(\mathrm{GOVT})+\mathrm{r}_{1 \mathrm{ij}}$

\section{Level 3:}

$\beta_{00 \mathrm{j}}=\gamma_{000}+\gamma_{001} .(\mathrm{NCI})+\gamma_{002} .(\mathrm{PCGDP})+\gamma_{003} .(\mathrm{G} 8)+\mathrm{u}_{00 \mathrm{j}}$
$\beta_{01 \mathrm{j}}=\gamma_{010}+\gamma_{011} .(\mathrm{NCI})+\gamma_{012} .(\mathrm{PCGDP})+\gamma_{013} .(\mathrm{G} 8)$
$\beta_{02 \mathrm{j}}=\gamma_{020}+\gamma_{021} .(\mathrm{NCI})+\gamma_{022} .(\mathrm{PCGDP})+\gamma_{023} .(\mathrm{G} 8)$
$\beta_{03 \mathrm{j}}=\gamma_{030}+\gamma_{031} .(\mathrm{NCI})+\gamma_{032} .(\mathrm{PCGDP})+\gamma_{033} .(\mathrm{G} 8)$
$\beta_{10 \mathrm{j}}=\gamma_{100}+\gamma_{101} .(\mathrm{NCI})+\gamma_{102 .}$ (PCGDP) $+\gamma_{103} .(\mathrm{G} 8)+\mathrm{u}_{10 \mathrm{j}}$
$\beta_{11 \mathrm{j}}=\gamma_{110}+\gamma_{111} .(\mathrm{NCI})+\gamma_{112} .(\mathrm{PCGDP})+\gamma_{113} .(\mathrm{G} 8)$
$\beta_{12 \mathrm{j}}=\gamma_{120}+\gamma_{121} .(\mathrm{NCI})+\gamma_{122} .(\mathrm{PCGDP})+\gamma_{123} .(\mathrm{G} 8)$
$\beta_{13 \mathrm{j}}=\gamma_{130}+\gamma_{131} .(\mathrm{NCI})+\gamma_{132 .}$ (PCGDP) $+\gamma_{133} .(\mathrm{G} 8)$

The interpretation of the coefficients is the same as explained above.

\section{Results}

I first applied the null model using the HLM 6.04 program, according to Snijders and Bosker (1999), Raudenbush and Bryk (2002) and Short, Ketchen Jr., Bennett and du Toit (2006, pp. 259-284).

Table 1 presents the variance decomposition among the levels. Thus, $6.429 \%$ of the performance variability occurred among firms $\left(\chi^{2}=812.201, \mathrm{p}<0.01\right)$ and a relevant percentage of the variance in performance $(95.570 \%)$ was due to the time evolution of each firm. On the other hand, a small percentage of the variance $(0.001 \%)$ was due to the differences among countries $\left(\chi^{2}=12.148, \mathrm{p}>0.050\right)$.

Table 1: Variance Decomposition: Null Model

\begin{tabular}{cccc}
\hline Fixed Effect & Coefficient & $\begin{array}{c}\text { Standard } \\
\text { Error }\end{array}$ & t \\
\hline General mean RET $\left(\square_{000}\right)$ & 1.171 & 1.504 & 0.778 \\
\hline Random Effect & Variance Component & df & $\chi^{2}$ \\
\hline
\end{tabular}

BBR, Braz. Bus. Rev. (Eng. ed., Online),

Vitória, v. 5, n. 3, Art. 1, p. 163 - 180, sep. - dec. 2008

www.bbronline.com.br 


\begin{tabular}{lccc}
\hline Time Variation $\left(\mathrm{e}_{\mathrm{tij}}\right)$ & 8830.704 & 505 & 812.201 \\
Variation among Firms $\left(\mathrm{r}_{0 \mathrm{ij}}\right)$ & $606.782^{* *}$ & & 17 \\
Variation among Countries & 0.104 & & 12.148 \\
$\left(\mathrm{u}_{00 \mathrm{j}}\right)$ & \% per Level & \\
$\quad$ Variance Decomposition & 95.570 & \\
\hline Level 1 (time) & 6.429 & \\
Level 2 (firm) & 0.001 & \\
Level 3 (country) & &
\end{tabular}

Tables 2 and 3 show the results of the models with the inclusion of the trend at level 1 , without and with random effects, respectively. The model with random effects (Table 2) shows that the year variable (linear trend) with fixed effect is significant $(t=6.433, \mathrm{p}<0.01)$. An analysis of Table 3, which presents the results of the linear trend model with random effects, shows that the variance component for the linear trend is also significant $\left(\square^{2}=\right.$ $651.003, \mathrm{p}<0.01)$.

Table 2: Variance Decomposition: Linear Trend Model without Fixed Effects

\begin{tabular}{lccc}
\multicolumn{1}{c}{ Fixed Effect } & Coefficient & $\begin{array}{c}\text { Standard } \\
\text { Error }\end{array}$ & t \\
\hline General mean RET $\left(\gamma_{000}\right)$ & $-8.100^{* *}$ & 1.396 & -5.809 \\
General mean of the growth rates & $2.067^{* *}$ & 0.321 & 6.433 \\
of RET $\left(\gamma_{100}\right)$ & Variance Component & Df & $\chi^{2}$ \\
\hline \multicolumn{1}{c}{ Random Effect } & & &
\end{tabular}

Level 1

Time Variation $\left(\mathrm{e}_{\mathrm{tij}}\right)$

8826.019

Level 2

Initial RET of the Firms ( $\left.\mathrm{r}_{0 \mathrm{ij}}\right)$

$581.709 * *$

505

810.743

Level 3

\begin{tabular}{llll} 
Mean RET of the Countries $\left(\mathrm{u}_{00 \mathrm{j}}\right)$ & 0.044 & 17 & 12.540 \\
\hline$* * \mathrm{p}<0.01$. &
\end{tabular}

Table 3: Variance Decomposition: Linear Trend Model with Fixed Effects

\begin{tabular}{lccc}
\multicolumn{1}{c}{ Fixed Effect } & Coefficient & Standard & t \\
\hline General mean RET $\left(\gamma_{000}\right)$ & $-7.970^{* *}$ & 1.4000 & -5.690 \\
$\begin{array}{l}\text { General mean of the growth rates } \\
\text { of RET RET }\left(\gamma_{100}\right)\end{array}$ & $2.037^{* *}$ & 0.327 & 6.233 \\
\hline \multicolumn{1}{c}{ Random Effect } & Variance Component & df & $\chi^{2}$ \\
\hline
\end{tabular}


Level 1

Time Variation $\left(\mathrm{e}_{\mathrm{tij}}\right)$

8795.974

Level 2

Initial RET of the Firms ( $\left.\mathrm{r}_{0 \mathrm{ij}}\right)$

$454.729 * *$

505

668.492

Rate of Change of the Trend of

the Firms $\left(r_{1 i j}\right)$

$1.163^{* *} \quad 505$

651.003

Level 3

Mean RET of the Countries $\left(\mathrm{u}_{00 \mathrm{j}}\right)$

0.195

17

4.091

Rate of Change of the Trend of

the Countries $\left(\mathrm{u}_{10 \mathrm{j}}\right)$

0.009

17

3.966

$* * \mathrm{p}<0.01$.

The results shown in Tables 1,2 and 3 support hypotheses 1, 2 and 4. However, hypothesis 3 is not supported, since there is no significant variability in the performance among firms from different countries over the time period studied.

Therefore, hypothesis 67 is automatically discarded, leaving only hypothesis 5 to analyze To do this, the complete model is tested, but without level 3, as follows:

Level 1:

$\mathrm{RET}_{\mathrm{ti}}=\pi_{0 \mathrm{i}}+\pi_{1 \mathrm{i}} \cdot \mathrm{ANO}_{\mathrm{ti}}+\mathrm{e}_{\mathrm{ti}}$

Level 2:

$\pi_{0 \mathrm{i}}=\beta_{00}+\beta_{01} .(\mathrm{IND})+\beta_{02} \cdot(\mathrm{COM})+\beta_{03} \cdot(\mathrm{GOVT})+\mathrm{r}_{0 \mathrm{i}}$

$\pi_{1 i}=\beta_{10}+\beta_{11} .(\mathrm{IND})+\beta_{12} .(\mathrm{COM})+\beta_{13} .(\mathrm{GOVT})+\mathrm{r}_{1 \mathrm{i}}$

Table 4 presents the results of this model.

Table 4: Variance Decomposition: Complete Model with Two Levels

Fixed Effect

General mean RET $\left(\beta_{00}\right)$

General mean RET $\left(\beta_{01}\right)$

General mean RET $\left(\beta_{02}\right)$

General mean RET $\left(\beta_{03}\right)$

General mean RET $\left(\beta_{10}\right)$

General mean RET ( $\left.\beta_{11}\right)$

General mean RET ( $\left.\beta_{12}\right)$

General mean RET ( $\left.\beta_{13}\right)$

\section{Coefficient}

$-11.165 * *$

$3.372 * *$

$5.592 *$

4.138

$3.227 * *$

$-1.521 * *$

$-1.437 *$

$-1.319$

\begin{tabular}{ccc}
$\begin{array}{ccc}\text { Standard } \\
\text { Error }\end{array}$ & $\mathbf{t}$ \\
\cline { 1 - 1 } 1.912 & & -5.839 \\
0.103 & & 32.738 \\
2.792 & & 2.003 \\
16.832 & & 0.246 \\
0.677 & & 4.767 \\
0.583 & & -2.609 \\
0.704 & -2.041 \\
2.398 & -0.550
\end{tabular}

Random Effect

Variance Component

df

$0^{2}$

BBR, Braz. Bus. Rev. (Eng. ed., Online), 
Level 1

Time Variation $\left(\mathrm{e}_{\mathrm{ti}}\right)$

8798.053

Level 2

Initial RET of the Firms $\left(\mathrm{r}_{0 \mathrm{i}}\right)$

$474.269 * *$

519

672.797

Rate of Change of the Trend of

the Firms $\left(\mathrm{r}_{1 \mathrm{i}}\right)$

$1.254 * *$

519

655.685

$* \mathrm{p}<0.05$.

$* * \mathrm{p}<0.01$.

Table 4 shows that the variables referring to the segment of activity (Industry or Commerce) are representative of the average performance and the performance growth rates among firms over the years. While the industrial firms have higher mean returns than commercial firms, they also have greater declines in profitability over time than the latter. The fact that a firm is state controlled does not influence the average performance or the evolution of that performance over the time period studied.

In general, four of the six hypotheses were supported by the results of the hierarchical models. The results obtained from these models of variance component analysis are not restricted, as presented, only to specification of the composition of the performance variance. They also allow analysis of the influence of specific firm characteristics on the performance over the years analyzed.

\section{Conclusions}

Many studies employing three-level hierarchical modeling with repeated measures, in which the third level represents the effect of the country of origin, have found significant variability among firms from different countries. Among these is the study by Goldszmidt, Brito and Vasconcelos (2007) for Brazil, with data from a sample drawn from Compustat Global. In the present study, in contrast, the absence of significant variability at the third level may be due to the fact that all the firms operate in Brazil, with the country of origin only differentiating the location of the parent company. This fact may be affecting the performance of the firms homogeneously, because of the country's characteristics, such as the tax burden, interest rate or availability of credit. This is evidence that there is no difference in the returns of multinationals operating in Brazil.

Hierarchical modeling permits the researcher to evaluate important nuances in longitudinal databases. However, the technique also has limitations involving determination of the research question, since it must be defined according to the natural hierarchical structure of the data and the logic with which the software works. If on the one hand this technique requires data to be nested at hierarchical levels, on the other it permits missing or censured data without the need to balance the data as in other techniques, such as structural equations (SHORT, KETCHEN Jr., BENNETT and du TOIT, 2006, pp. 259-286).

A contribution of this study is its estimation of the impact of temporal variation on firms' performance, as well as among firms and among countries. Many authors have structured studies along this line, providing researchers a possibility to prioritize the aspects that warrant greater attention. If the country effect is stronger, then there should be more focus on the relative effects of differences among countries for the composition of performance. If on the other hand the differences among firms explain most of the variance, as in this study, a 
focus on strategic management and the differences among organizations is a more fruitful approach.

Another contribution of this study is the addition of predictive variables at the firm level. Many articles have studied variance decomposition, but without evaluating the impacts of the presence of certain variables, only seeking to determine where most of the variability occurs (RUMELT, 1991, pp. 167-185). According to Short, Ketchen Jr., Bennett and du Toit (2006, pp. 25-284), applications with linear hierarchical models offer researchers new possibilities to test more complicated hypotheses without the risk of violating the premises inherent in other techniques, such as ordinary least squares regression.

Other approaches should be studied regarding companies in Brazil. The inclusion of predictive variables and even the investigation a possible effect of the state where firms operate at level 3 can be applied to determine new strategies and to create different models, seeking a better understanding of the mechanisms underlying the factors affecting firms' performance over time.

\section{REFERENCES}

ADNER, R.; HELFAT, C. E. Corporate effects and dynamic managerial capabilities. Strategic Management Journal, v. 24, n. 10, pp. 1011-1025, 2003.

BARTH, M. E.; BEAVER, W. H.; LANDSMAN, W. The relevance of the value-relevance literature for financial accounting standard setting: Another view. Journal of Accounting and Economics, v. 31, n. 1-3, pp. 77-104, 2001.

BERGH, D. D. Watch the time carefully: The use and misuse of time effects in management research. Journal of Management, v. 19, n. 3, pp. 683-705, 1993.

Problems with repeated measures analysis: Demonstration with a study of the diversification and performance relationship. Academy of Management Journal, v. 38, n. 6, pp. 1692-1708, 1995.

BLIESE, P. D.; PLOYHART, R. E. Growth modeling using random coefficient models: Model building, testing, and illustrations. Organizational Research Methods, v. 5, n. 4, pp. 362-387, 2002.

BOWMAN, E. H; HELFAT, C. E. Does corporate strategy matter? Strategic Management Journal, v. 22, n. 1, pp. 1-23, 2001.

BRITO, L. A. L.; VASCONCELOS, F. C. How much does country matter? In: XXVII ENCONTRO DA ASSOCIAÇÃO NACIONAL DOS PROGRAMAS DE PÓSGRADUAÇÃO EM ADMINISTRAÇÃO, 2003, Atibaia. Annals of the Congress.

BRUSH, T. H.; BROMILEY, P. What does a small corporate effect mean? A variance components simulation of corporate and business effects. Strategic Management Journal, v. 18, n. 10, pp. 825-835, 1997.

BRUSH, T. H.; BROMILEY, P.; HENDRICKX, M. The relative influence of industry and corporation on business segment performance: An alternative estimate. Strategic Management Journal, v. 20, n. 6, pp. 519-547, 1999.

CHANG, S.; SINGH, H. Corporate and industry effects on business unit competitive position. Strategic Management Journal, v. 21, n. 7, pp. 739-752, 2000.

CHRISTMANN, P.; DAY, D. L.; YIP, G. S. The relative influence of country conditions, industry structure and business strategy on MNC subsidiary performance. Journal of International Management, v. 5, n. 4, pp. 241-265, 1999.

BBR, Braz. Bus. Rev. (Eng. ed., Online),

Vitória, v. 5, n. 3, Art. 1, p. 163 - 180, sep. - dec. 2008

www.bbronline.com.br 
COLLINS, J. M. A market performance comparison of U.S. firms active in domestic, developed, and developing countries. Journal of International Business Studies, v. 21, pp. 271-288, 1990.

DEADRICK, D. L.; BENNETT, N.; RUSSELL, C. J. Using hierarchical linear modeling to examine dynamic performance criteria over time. Journal of Management, v. 23, n. 6, pp. 745-757, 1997.

DRAPER, D. Inference and hierarchical modeling in the social sciences. Journal of Educational and Behavioral Statistics, v. 20, n. 2, pp. 115-147, 1995.

GELMAN, A. Multilevel (hierarchical) modeling: What it can and cannot do. Technometrics, v. 48, n. 3, pp. 432-435, 2006.

GOLDSTEIN, H. Multilevel Statistical Models. 3rd ed. London: Arnold, 2003. GOLDSZMIDT, R. G. B.; BRITO, L. A. L.; VASCONCELOS, F. C. O efeito país sobre o desempenho da firma: uma abordagem multinível. In: III ENCONTRO DE GOVTUDOS EM GOVTRATÉGIA, 2007, São Paulo. Annals of the Congress.

HAWAWINI, G.; SUBRAMANIAN, V.; VERDIN, P. The home country in the age of globalization: How much does it matter for firm performance? Journal of World Business, v. 39, n. 2, pp. 121-135, 2004.

HOFMANN, D. A. An overview of the logic and rationale of hierarchical linear models.

Journal of Management, v. 23, n. 6, pp. 723-744, 1997.

HOFMANN, D. A.; JACOBS, R.; BARATTA, J. E. Dynamic criteria and the measurement of change. Journal of Applied Psychology, v. 78, n. 2, pp. 194-204, 1993.

HOLTHAUSEN, R. W.; WATTS, R. L. The relevance of the value-relevance literature for financial accounting standard setting. Journal of Accounting and Economics, v. 31, n. 1-3, pp. 3-75, 2001.

HOUGH, J. R. Business segment performance redux: a multilevel approach. Strategic Management Journal, v. 27, n. 1, pp. 45-61, 2006.

HOX, J. Multilevel Analysis: Techniques and Applications. Mahwah: Lawrence Erlbaum, 2002.

IUDÍCIBUS, S.; LOPES, A. B. (coord.) Teoria Avançada de Contabilidade. São Paulo: Atlas, 2004.

KREFT, I.; de LEEUW, J. Introducing Multilevel Modeling. London: Sage, 1998.

LIMA, G. A. S. F.; LIMA, I. S.; FÁVERO, L. P. L; GALDI, F. C. Influência do disclosure voluntário no custo de capital de terceiros. In: $7^{\circ}$ CONGRESSO USP DE CONTROLADORIA E CONTABILIDADE, 2007, São Paulo. Annals of the Congress.

MAKINO, S.; BEAMISH, P. W; ZHAO, N. B. The characteristics and performance of Japanese FDI in less developed and developed countries. Journal of World Business, v. 39, n. 4, pp. 377-392, 2004.

MAKINO, S.; ISOBE, T.; CHAN, C. M. Does country matter? Strategic Management Journal, n. 25, n. 10, pp. 1027-1043, 2004.

MAURI, A. J.; MICHAELS, M. P. Firm and industry effects within strategic management: An empirical examination. Strategic Management Journal, v. 19, n. 3, pp. 211-219, 1998.

MCGAHAN, A. M.; PORTER, M. E. How much does industry matter, really? Strategic Management Journal, v. 18, n. S1, pp. 15-30, 1997. 
MISANGYI, V.; LEPINE, J. A.; ALGINA, J.; GOEDDEKE Jr., F. The adequacy of repeatedmeasures regression for multilevel research. Organizational Research Methods, v. 9, n. 1, pp. 5-28, 2006.

PRICE, P. N.; NERO, A. V.; GELMAN, A. Bayesian prediction of mean indoor radon concentrations for Minnesota counties. Health Physics, v. 71, n. 6, pp. 922-936, 1996.

RAUDENBUSH, S.; BRYK, A. Hierarchical Linear Models: Applications and data analysis methods. 2nd ed. Thousand Oaks: Sage, 2002.

RAUDENBUSH, S.; BRYK, A.; CHEONG, Y. F.; CONGDON, R.; du TOIT, M. HLM 6:

Hierarchical linear and nonlinear modeling. Lincolnwood: Scientific Software International, Inc., 2004.

ROQUEBERT, J. A.; PHILLIPS, R. L.; WGOVTFALL, P. A. Market vs. management: What 'drives' profitability? Strategic Management Journal, v. 17, n. 8, pp. 653-664, 1996.

RUEFLI, T. W.; WIGGINS, R. R. Industry, corporate and segment effects and business performance: A non-parametric approach. Strategic Management Journal, v. 24, n. 9, pp. 861-879, 2003.

RUMELT, R. P. How much does industry matter? Strategic Management Journal, v. 12, n. 3, pp. 167-185, 1991.

SCHMALENSEE, R. Do markets differ much? The American Economic Review, v. 75, n. 3, pp. 341-351, 1985.

SHORT, J. C.; KETCHEN Jr., D. J.; BENNETT, N.; du TOIT, M. An examination of firm, industry, and time effects on performance using random coefficients modeling. Organizational Research Methods, v. 9, n. 3, pp. 259-284, 2006.

SHORT, J. C.; KETCHEN Jr., D. J.; PALMER, T. B.; HULT, G. T. M. Firm, strategic group, and industry influences on performance. Strategic Management Journal, v. 28, n. 2, pp. 147-167, 2007.

SNIJDERS, T. A. B.; BOSKER, R. J. Multilevel Analysis: An introduction to basic and advanced multilevel modeling. London: Sage, 1999.

SOTO, J. L. G.; MORERA, M. C. Modelos jerárquicos lineales. Madrid: La Muralla, 2005. WATTS, R. L.; ZIMMERMAN, J. L. Positive Accounting Theory. Englewood Cliffs: Prentice Hall, 1986. 